\title{
Stream bank and sediment movement associated with 2008 flooding, South Fork lowa River
}

\section{M.D. Tomer and J.D. Van Horn}

\begin{abstract}
Stream bank erosion can damage riparian systems and impact the use of water downstream. Risks of bank erosion increase during extreme flood events, and frequencies of extreme events may be increasing under a changing climate. We assessed bank erosion within the South Fork Iowa River (SFIR) watershed caused by 2008 flooding, which set flood stage records in many eastern Iowa streams. Bank positions before and after 2008 were digitized using rectified aerial infrared imagery and overlaid. Differences in stream bank lines were mapped as polygons; those $<4 \mathrm{~m}(13 \mathrm{ft})$ wide were deleted to eliminate polygons possibly formed by digitizing error. A high-resolution ( $2 \mathrm{~m}[6.6 \mathrm{ft}]$ grid) elevation model was used to map elevation changes associated with both erosional and depositional polygons. We estimated that along three streams (SFIR, Tipton Creek, and Beaver Creek) with watershed areas of 20,000 to 36,500 ha $(49,000$ to $90,150 \mathrm{ac})$, the 2008 floods widened the channels by 0.5 to $1.1 \mathrm{~m}$ (1.6 to $3.6 \mathrm{ft})$, and about $8.5 \mathrm{ha}(21 \mathrm{ac})$ of land was lost to become part of these channels. The volume and mass losses associated with this movement totaled $117,000 \mathrm{~m}^{3}$ $\left(153,000 \mathrm{yd}^{3}\right)$, which comprised on average $1.1 \mathrm{Mg} \mathrm{m}^{-1}\left(1 \mathrm{Mg} \mathrm{m}^{-1}=1.01 \mathrm{tn} \mathrm{yd}^{-1}\right)$ of stream length. Below the Tipton Creek confluence, the middle SFIR (58,500 ha [144,500 ac]) was widened by more than $4.4 \mathrm{~m}(14.4 \mathrm{ft})$, with about $8.1 \mathrm{Mg}(8.9 \mathrm{tn})$ of sediment lost per meter of stream. The 2008 floods substantially altered these channels, but using images from helicopter flights from late 2008 and 2009, we found evidence that where riparian buffers were kept in ungrazed, grassy vegetation, there was less bank erosion than where grazed pastures lined these channels. Riparian management systems may reduce stream bank erosion even under extreme flooding.
\end{abstract}

Key words: extreme flood events-geographic information systems-geomorphologystream bank erosion

\begin{abstract}
Sediment loads in streams result in a range of environmental and economic impacts, including effects on aquatic habitat and fisheries (Gray et al. 2014; Quist and Schultz 2014) and increased costs of flood control and dredging (Wesche and Issak 1999). The erosion of stream banks and channels comprises a dominant component of suspended sediment losses from agricultural watersheds in the United States (Simon and Klimetz 2008; Wilson et al. 2008). Agricultural clearing of land during the settlement of North America dramatically increased soil erosion (Montgomery 2007), leading to sediment deposition in river valleys, which has had legacy impacts on sediment loads in
\end{abstract}

influenced by land use (Zaimes 2008) and geomorphic controls on channel formation processes, which include resistance of bed materials to down-cutting and differences in base level controls that are typically found at river confluences. Detailed discussion on Midwest studies of channel adjustments to sedimentation are available (Knox 2006; Lecce 1997).

The magnitude of bank erosion losses has been evaluated in the upper Midwest using erosion pins (Palmer et al. 2014; Zaimes et al. 2008) and sequential aerial surveys using Light Detection and Ranging (LiDAR) systems (Kessler et al. 2012; Thoma et al. 2005). Using pin measurements, bank recession rates were estimated to average $0.19 \mathrm{~m} \mathrm{y}^{-1}$ $\left(0.62 \mathrm{ft} \mathrm{yr}^{-1}\right)$ in a seven-year study of Walnut Creek in Iowa (Palmer et al. 2014), and to range between 0.14 and $0.52 \mathrm{~m} \mathrm{y}^{-1}$ (0.46 to $1.71{\mathrm{ft} \mathrm{yr}^{-1}}^{-1}$ in a single-year study conducted under multiple vegetative cover types (Zaimes et al. 2008) along Bear Creek in Iowa. Also, in south-central Iowa, Tufekcioglu et al. (2012) found that stream banks between 1 and $3 \mathrm{~m}$ (3.3 and $9.8 \mathrm{ft}$ ) high and located within grazed pastures eroded between 0.09 and $0.38 \mathrm{~m} \mathrm{y}^{-1}$ ( 0.3 to $\left.1.2 \mathrm{ft} \mathrm{yr}^{-1}\right)$; the eroding banks occupied from $13 \%$ to $36 \%$ of the banks' lengths among the pastured study sites. Pin measurements may only be feasible along small headwater streams and are usually focused along eroding banks of limited extent compared to full lengths of stream reaches. Remote data acquisition using LiDAR systems offers an advantage where access along longer lengths of stream, larger rivers, or high banks is not feasible. Several studies have used LiDAR surveys to assess river bank erosion in southern Minnesota. Thoma et al. (2005) compared two helicopter-borne LiDAR surveys flown in spring of 2001 and 2002, and estimated a volume loss of 281,454 $\mathrm{m}^{3}$ $\left(367,500 \mathrm{yd}^{3}\right)$ along a $56 \mathrm{~km}$ (34.6 mi) length of the Blue Earth River. Kessler et al. (2012) followed this effort by comparing LiDAR surveys conducted in 2005 and 2009 along the Blue Earth and six other tributaries to the Minnesota River. Mass wasting from

Mark D. Tomer is a research soil scientist for USDA Agricultural Research Service (ARS) National Laboratory for Agriculture and the Environment in Ames, lowa. Jessica D. Van Horn is a physical science technician for USDA ARS National Laboratory for Agriculture and the Environment in Ames, lowa. 
high (>3 m [9.8 ft]) banks was responsible for most of the volume losses found among these rivers.

Study Area Description and Objective. This paper presents information on the extent of stream channel widening that was associated with a large flood event along the South Fork Iowa River (SFIR), a fourth-order river in north-central Iowa. The SFIR (Tomer et al. 2008a, 2008b) comprises a 78,000 ha $(193,000 \mathrm{ac})$ watershed, including tributaries Tipton Creek and Beaver Creek (figure 1). The SFIR is situated on the eastern margin of the Des Moines Lobe (Prior 1991), which is a region of recent (approximately 12,000 years) Wisconsinan-age glaciation. The watershed's uplands comprise a glacial plain with gently rolling terrain, common glacial depressions, and poorly drained soils, and have not been well dissected by streams. However, near its outlet and confluence with the Iowa River, the SFIR cut through the terminal moraine of the Des Moines Lobe during times of glacial melt. The meltwaters carved the lower SFIR and tributary stream valleys, and partially filled those valleys with outwash gravels (Yan et al. 2010). These stream valleys occupy the lower half of the watershed. Subsequently, during the Holocene, the outwash deposits in most places became mantled by fine textured alluvial deposits, typically 1 to $2 \mathrm{~m}$ (3.2 to $6.5 \mathrm{ft}$ ) thick, as the glacial plain forming the watershed uplands comprised a complex of tallgrass prairie and depressional wetlands that released little runoff to the streams. The area was settled for farming by European immigrants beginning around 1840. An extensive network of ditches and subsurface drainage tiles was later installed during the first part of the 20th century to enable agricultural production essentially across the entire landscape. These modifications enabled the native productivity of the prairie soils to be utilized in agricultural production, and the network of ditches installed in the SFIR watershed effectively extended the stream network west and north into the uplands of the watershed's glacial plain. This conversion substantially increased runoff, soil erosion, and stream discharge volumes. Some of the eroded sediment was deposited in the SFIR stream valleys, documented by Yan et al. (2010). As happened in much of the central United States, the recently accumulated sediment slowed stream conveyance and increased flooding problems (Simon and Rinaldi 2006). Channelization and stream straightening were undertaken in the SFIR to increase stream conveyance, as occurred elsewhere in the Mississippi River basin (Simon and Rinaldi 2006). These changes were documented in the SFIR by Yan et al. (2010), who found that the SFIR and Tipton and Beaver creeks lost a combined $14 \mathrm{~km}(8.7 \mathrm{mi})$ of channel length between 1939 and 2002, from a total of about $125 \mathrm{~km}(77.6 \mathrm{mi})$ as measured using rectified 1939 aerial photographs.

This paper extends the documented history of channel movement in the SFIR and reports on changes along the stream banks of the SFIR and Tipton and Beaver creeks that occurred between 2002 and 2009. The largest runoff events during this seven year period (2002 to 2009) comprised major flooding during May and June of 2008, which caused substantial losses of nutrients and sediment (Hubbard et al. 2011). Our objective was to estimate the widths, volumes, and masses of bank movement that could be attributed to the 2008 flood event along the SFIR and its tributaries, and determine whether/how riparian land cover may have influenced this bank movement. A geomorphic survey of the SFIR stream banks in 2006 identified channel widening as dominant processes (Simon and Klimetz 2008), but stream banks watershed-wide were visibly changed after the 2008 flood event. Tomer et al. (2016) showed that, between 2002 and 2008, approximately half the surface runoff from two cropped fields in the SFIR watershed occurred in 2008, and that about $90 \%$ of the total occurred during 2007 and 2008. Wet conditions in 2007 contributed to the antecedent conditions that enabled the 2008 flood to reach its magnitude (Hubbard et al. 2011).

Other pertinent research using data from SFIR stream gages has been published. The SFIR hydrologic flows and nutrient loads that occurred during 2000 to 2011 have been reported by Tomer et al. (2008b) and Kalkhoff et al. (2015). Tomer et al. (2010) conducted a hydrograph separation study for a single September of 2006 rainfall runoff event in Tipton Creek, and, using radionuclide ratios, found channel contributions dominated sediment loads. However, this was not a channel-altering event; stream stages remained within bank, and bed scour, rather than bank erosion, was presumed to dominate because sediment concentrations were only increased during the rising limb of the hydrograph, not during recession.

\section{Materials and Methods}

Color infrared photographic imagery from 2002 and 2009 (Iowa State University 2016) was used to hand digitize stream bank lines at a scale of 1:2,000. The state of Iowa has obtained photographic imagery during many recent years, but alternated the type of imagery and the season of acquisition; 2002 and 2009 were the two years during the 2000 to 2010 decade where near-infrared imagery was acquired in the spring, during leaf-off of hardwood trees, which allows water features to be most clearly delineated. Specifically, the 2002 imagery used in this study was acquired on April 9 and May 6, and the 2009 imagery was collected on April 3,14, and 17 (Iowa State University 2016). Duplicating the study extent chosen by Yan et al. (2010), the SFIR, Tipton Creek and Beaver Creek stream banks were digitized along middle and lower reaches where the streams meandered within the watershed's naturally formed alluvial valleys (figure 2). Stream reaches found further upstream, where naturally formed channels have been merged into dug and fully straightened ditches, were not included.

The digitized bank lines were then used to generate polygons representing areas of channel movement. The bank lines were overlaid and areas where the lines diverged were formed into polygons, which were filtered to identify where channel movement was most apparent. The filtering process first buffered the polygons inward by $2 \mathrm{~m}$ (6.6 $\mathrm{ft}$ ) to account for digitizing error (Micheli and Kirchner 2002). This buffering made the polygons smaller, but the $2 \mathrm{~m}$ buffer was deemed appropriate considering that for a $1: 2,000$ scale image, $2 \mathrm{~m}$ on the ground is represented by only $1 \mathrm{~mm}$ (0.04 in) on the map imagery. The inward buffering meant that the area and volume estimates disregard all polygons less than $4 \mathrm{~m}$ (13 ft) wide, which could have been formed by additive digitizing errors of $1 \mathrm{~mm}$. Then, slivers and small polygons that remained after the buffering were filtered out by deleting polygons with an area-perimeter ratio $<0.5 \mathrm{~m}^{2} \mathrm{~m}^{-1}\left(1.64 \mathrm{ft}^{2}\right.$ $\left.\mathrm{ft}^{-1}\right)$. The polygons that remained were classified to separate areas of stream bank erosion and deposition. That is, polygons that were part of the channel in the 2002 imagery but not in the 2009 imagery were classified as depositional, and movement polygons that were part of the channel in 2009 but not in the 2002 imagery were classified as erosional. 
Before calculating channel erosion and deposition estimates, the data set was inspected for sections of channelization as well as areas of false movement. For example, a section of channel where the erosion polygon was edited to reflect the actual area of erosion is shown (figure 3). In 2002 this section of channel had a narrow branch not digitized as part of the main channel, but by 2009 this branch had widened and was digitized as the more recent bank line. The area between the 2002 and 2009 bank lines was considered erosion, but visually it is clear that total area did not erode as the island was still present in 2009. Several places were found where lengths of stream were channelized (as part of road and bridge repairs that closely followed the 2008 flooding), and a small number of channel cutoffs were removed from the polygon data before being used in further calculations.

A $2 \mathrm{~m}(6.6 \mathrm{ft})$ grid digital elevation model (DEM) derived from LiDAR data collected during 2009 to 2010 provided data for volume estimations. As with the color infrared imagery, the LiDAR acquisition occurred under leaf-off conditions, but one season later with acquisition dates for the SFIR and Tipton Creek occurring on November 27, 2009, then on May 17, 2010, for Beaver Creek. The intervening time between the 2009 photography and LiDAR acquisition included several runoff events, but less than half the runoff observed during 2008 (Tomer et al. 2010). The DEM was overlaid with the stream movement polygons. Depositional polygons were buffered outward $2 \mathrm{~m}$ (i.e., to the original digitized area), and the minimum elevation for each depositional polygon area was extracted. In the case of depositional polygons, the $2 \mathrm{~m}$ outward buffer allowed the minimum elevation to best represent the channel elevation. Note these depositional polygons were typically point/bar deposits (figure 4). This minimum elevation was then subtracted from actual elevation values for all $2 \mathrm{~m}$ grid cells entirely within the original (as digitized) polygon. The average of these elevation differences was calculated for each depositional polygon. This average was then multiplied by the inwardly buffered polygon area giving an estimated volume of deposition in cubic meters.

Volumes lost from erosional polygons could not be based on elevations of grid cells within these polygons because all the elevation values within the erosional poly-

\section{Figure 1}

General map of the South Fork lowa River watershed.

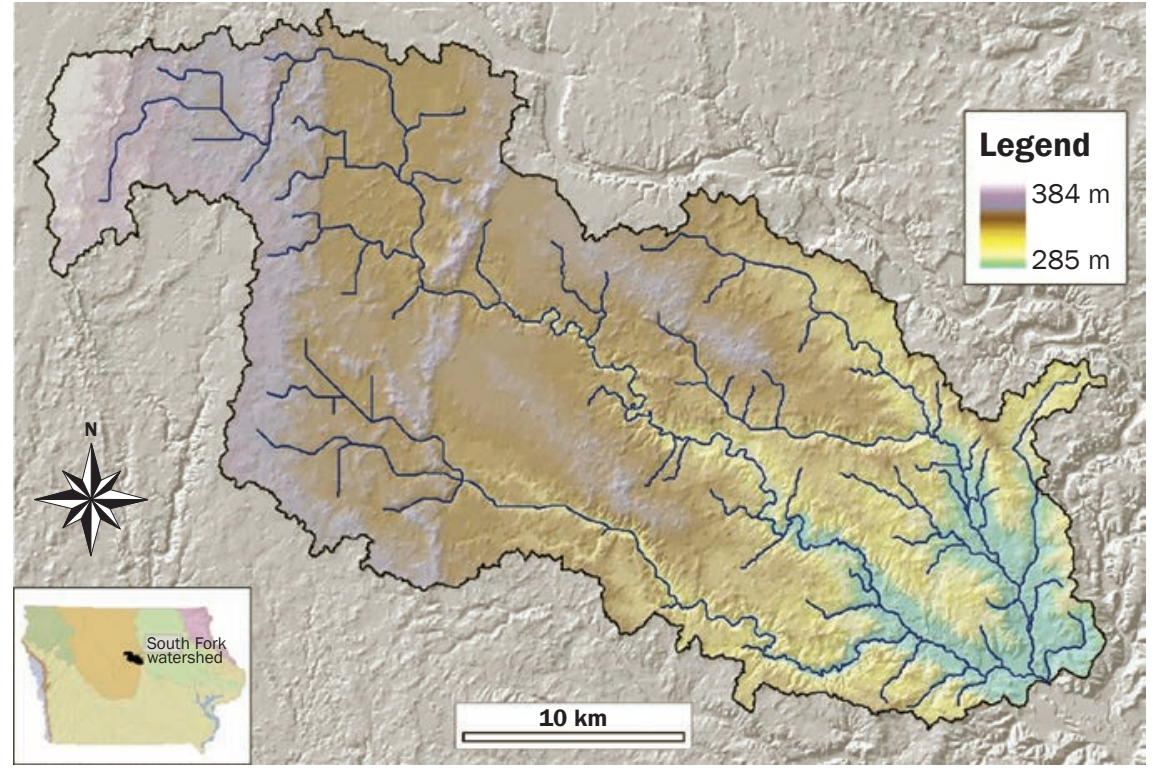

\section{Figure 2}

Map showing the extent of channels delineated for analysis, including the South Fork lowa River, and Tipton Creek and Beaver Creek tributaries. Overlaid imagery includes a hillshade and 2009 aerial imagery.

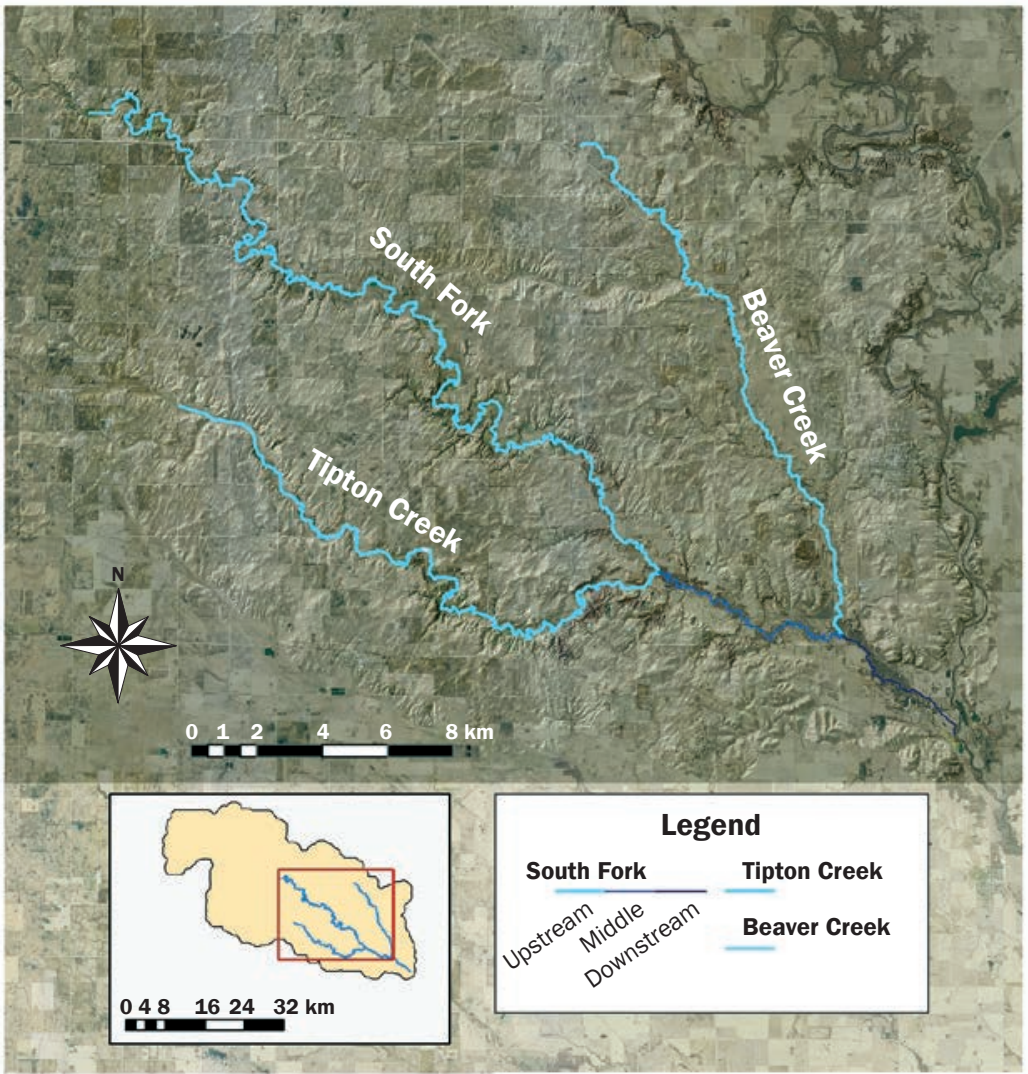




\section{Figure 3}

Example showing how visual review was used to detect and exclude polygons not appropriately classified as erosional or depositional. Manual editing was done to exclude the island visible in the right image from the total area of movement.

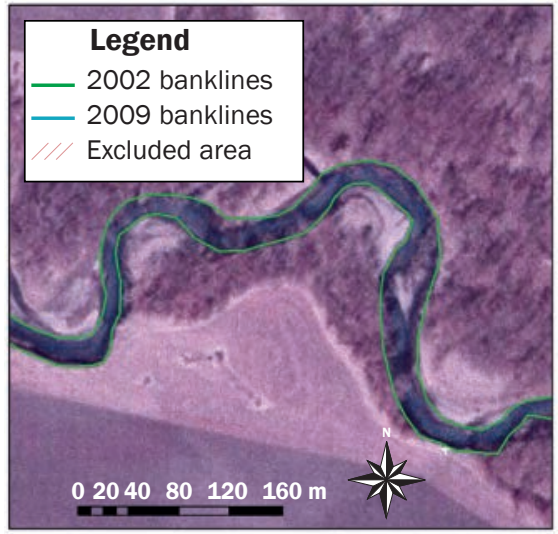

gons would represent the channel elevation. Therefore, using data found adjacent to (outside of) each of these polygons, we estimated the surface elevation of the erosional polygon prior to the erosional event. The erosional polygons were buffered outward by $5 \mathrm{~m}(16.4 \mathrm{ft})$, creating a "ring" around each. Note this $5 \mathrm{~m}$ outward buffer thereby went $3 \mathrm{~m}$ (9.8 ft) beyond the originally digitized polygon to include areas just above the bank on one side of each erosional polygon.

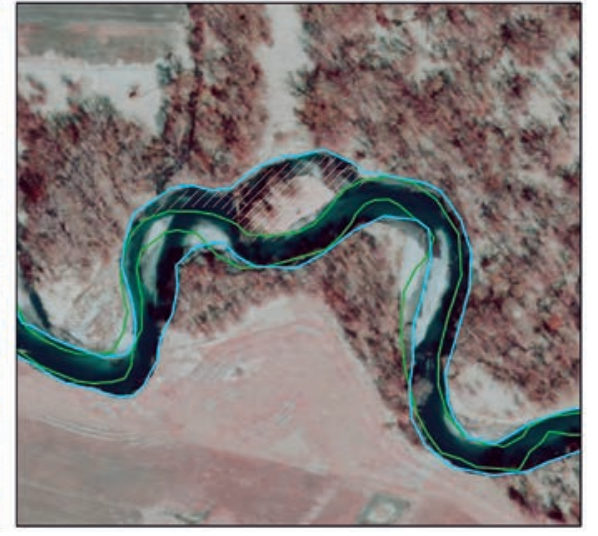

The original polygons' extents often fell completely onto in-channel grid cells, and adjoining grid cell elevations were needed to estimate bank heights and volume losses (figure 4). These $5 \mathrm{~m}$ buffers were split in two to separate channel and bank sides of the buffer. Median elevation values were calculated for both the channel- and bankside areas of the $5 \mathrm{~m}$ buffer. The median channel side values were subtracted from their corresponding median bank side values to result in a relative difference in elevation from bank to channel. We used median values here to minimize impacts of increased data skew where banks were highest, and be conservative in estimating bank heights. The estimated bank height was multiplied by erosion polygon's (inwardly buffered) area, resulting in a volume for each erosion area. Examples of erosional and depositional polygons with these buffering features used for elevation and volume calculations are shown in figure 4 .

Mass estimates were finally calculated by multiplying volumes $\left(\mathrm{m}^{3}\right)$ by a bulk density

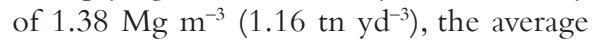
bulk density of postsettlement alluvium reported by Yan et al. (2010). Underlying and finer textured Holocene deposits had a slightly greater $(p<0.10)$ density of 1.43

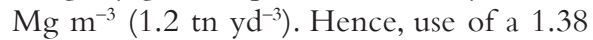
$\mathrm{Mg} \mathrm{m}^{-3}$ provided a conservative estimate of mass. Each step in this sequence of calculations was intended to avoid overestimating areas, heights, and/or volumes. Erosional and depositional volumes were summed for each stream bank and then summed to obtain estimates for the full reach of each stream. Note the SFIR channel data were divided into separate reaches found

\section{Figure 4}

Example showing buffered erosional polygons and depositional polygons. Note the erosional polygon is only shown as part of the channel in the 2009 image, while the depositional polygon is only shown as part of the channel in the 2002 image. The erosional polygons were buffered $5 \mathrm{~m}$ outward to obtain bank elevations for estimating volume losses. Depositional polygons were buffered $2 \mathrm{~m}$ so that minimum elevations used to estimate deposition volumes represented the channel elevation. The hollow area in both erosional and depositional polygons represents the inwardly buffered polygon, which provided areas used to calculate volumes (see text).

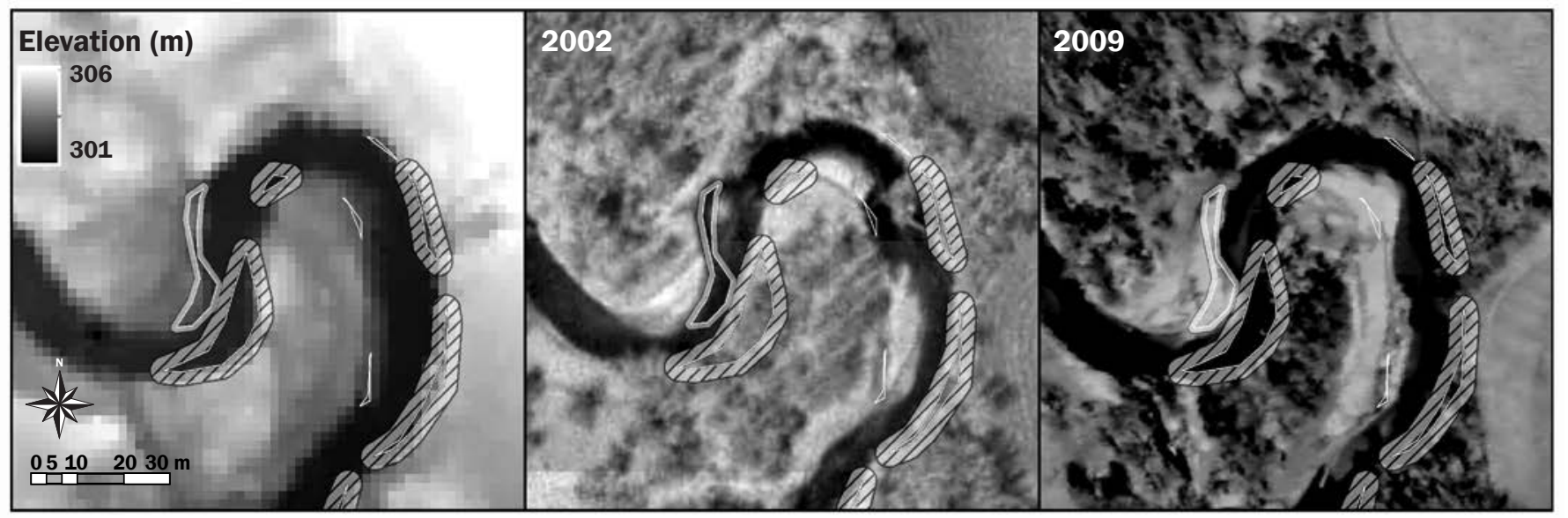

\section{Legend}
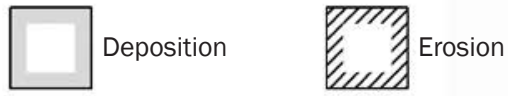
upstream and downstream of the confluence with Tipton Creek.

We primarily focus our reported results on comparing stream movement data among these two tributaries and the upper section of the SFIR (i.e., above the confluence with Tipton Creek; figure 2). Analysis of the middle SFIR reach (between the Tipton and Beaver confluences) is reported separately because the middle SFIR, below the Tipton Creek confluence, had substantially larger flows and different channel characteristics, and because changes in geomorphic processes can be anticipated below stream confluences (Rhoads and Kenworthy 1998). Our assessment did not extend below the confluence of SFIR with Beaver Creek (figure 2), which is about $8 \mathrm{~km}$ (5 $\mathrm{mi}$ ) above the SFIR confluence with the Iowa River. Iowa River flooding in 2008 sent backwater up-channel along the SFIR, and floodplain and landscape features differ below the Beaver confluence, which is also where the SFIR flows out of the Des Moines Lobe landform region.

Accuracy of LiDAR elevation data was assessed relating data from 22 surveyed stream cross sections, obtained using kinematic global positioning system (GPS) survey equipment, to LiDAR grid elevations. The cross section surveys were conducted in 2005 to 2006 (various dates), but were conducted in places with stable banks as a matter of safety and access, and hence all these cross sections were in places where bank movement polygons were not present. We separated these elevation comparisons to indicate absolute differences in average elevations by transect and relative differences within transects. That is, average elevations were compared by transects, then specific point/grid data were compared after subtracting the transect's average elevation, to determine reliability of relative local differences, which we used in making the volume estimations.

Summary statistics were calculated by stream reach including channel length, sinuosity, channel slope, and a widening ratio (net area of bank loss divided by channel length). Channel length was determined using the stream center lines, sinuosity was calculated as the ratio of the length to the channel line to the straight line distance from the stream length's beginning to end, and slope was determined by the change in elevation divided by the length of the chan- nel center line. These statistics were used to help explain variation of channel movement within the South Fork watershed. Riparian land use was assessed using the 2009 coverage of the Cropland Data Layer (USDA NASS 2016), filtered to majority land cover type (i.e., perennial grass, forest, crop, or other) along a $20 \mathrm{~m}$ (66 ft) buffer on each side of the stream. Cover types were filtered to represent majority cover within field boundaries (i.e., what the dominant cover type was), which were assembled as described by Tomer et al. (2015). We also assessed whether the streams varied in their distribution of counted erosional polygons by land cover type using binomial statistics. Observations and oblique photographs taken during low altitude helicopter flights in November of 2008 and April of 2009 were used to support interpretations.

\section{Results and Discussion}

Comparing Channel Movement among Tributaries. Among the upper SFIR and Tipton and Beaver creeks, we identified 733 erosional and 285 depositional polygons representing bank movement (table 1). The smallest of these polygons were 8 to $11 \mathrm{~m}^{2}$ (9.5 to $13.1 \mathrm{yd}^{2}$ ) depending on the stream and type of movement, but this minimum size was essentially determined by filtering of small and/or narrow polygons. The largest erosional polygons were $1,272 \mathrm{~m}^{2}(1,521.3$ $\mathrm{yd}^{2}$ ) along the SFIR, $595 \mathrm{~m}^{2}\left(711.6 \mathrm{yd}^{2}\right)$ along Tipton Creek, and 1,598 $\mathrm{m}^{2}$ (1,911.2 $\left.\mathrm{yd}^{2}\right)$ along Beaver Creek. The largest depositional polygons were $995 \mathrm{~m}^{2}\left(1,190 \mathrm{yd}^{2}\right)$ along the SFIR, 1,204 $\mathrm{m}^{2}\left(1,439.9 \mathrm{yd}^{2}\right)$ along Tipton Creek, and 1,259 $\mathrm{m}^{2}$ (1,505.7 $\mathrm{yd}^{2}$ ) along Beaver Creek. When combined among the streams, results (table 1) show net bank losses during 2002 to 2009 were estimated to be about 8.5 ha $(21 \mathrm{ac})$ of land, which was lost to bank erosion and became part of these three stream channels. The losses were not uniform among the streams surveyed, as Beaver Creek was widened by

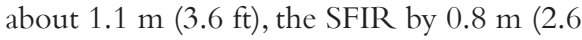
$\mathrm{ft}$ ), and Tipton Creek by nearly $0.5 \mathrm{~m}(1.6 \mathrm{ft}$; table 2). These amounts of channel expansion were greater, but within the same order of magnitude, when compared to annual rates of erosion reported for exposed banks of other Iowa streams (Palmer et al. 2014; Tufekcioglu et al. 2012; Zaimes et al. 2008), but are averaged over the entire length of these three channels. Note the 2008 flood- ing reduced the length of all three streams, and the sinuosity of Tipton and Beaver creeks (table 2). The most sinuous stream, the SFIR, showed the least reduction in length. The channel gradients may be high for the US Midwest, but reflect the transition from the recent glacial landform region (Des Moines Lobe) forming the headwaters (to the west), to where the watershed outlets onto an older (pre-Wisconsinan) landform region (to the east).

The differences in relative widening were affected by land cover (presented below), stream sinuosity (table 2), and watershed size. Beaver Creek had the straightest channel, the least riparian forest cover, and the greatest channel widening. Tipton Creek had the greatest amount of riparian forest cover, a sinuosity that was intermediate between the other two streams, and showed the least channel widening. Tipton and Beaver creeks are similar in size, about 20,000 ha $(45,000 \mathrm{ac})$. The SFIR is somewhat larger, draining about 36,500 ha $(90,000 \mathrm{ac})$ above its confluence with Tipton Creek, and has intermediate forest cover, the most sinuous channel, and widening that is intermediate between the other two streams.

We separated the net stream movement data by stream side to identify any evidence of stream migration. The amounts of bank movement differed between banks for each stream, particularly for Tipton Creek, which actually showed a small net deposition along the left (northern) bank (table 1), suggesting the stream migrated southward. Similarly for the SFIR, there was more area of bank loss on the right (southwestern) bank. In contrast, there was more erosion estimated for the left (eastern) banks along Beaver Creek. There is no clear reason to expect net stream movement/widening in any given direction within these valleys filled with glacial outwash, and we found no literature reporting stream migration rates beyond the scale of a single meander. These values are, therefore, of uncertain significance. Relative projection errors between the 2002 and 2009 rectified photo-coverages averaging only a few decimeters (i.e., less than $1 \mathrm{ft}$ ) could be enough to cause this apparent net stream movement.

Accuracy Assessment-Elevation Data. The assessment comparing elevations obtained using GPS survey equipment located along 22 stream cross sections with elevations of corresponding grid cell locations within the LiDAR based DEM were 
Table 1

Comparison of bank movement polygons, areas of movement, and volumes for three streams in the South Fork lowa River (SFIR) watershed. Volumes by bank side are also given.

\begin{tabular}{lrrr}
\hline Stream & Erosion & Deposition & Total (net) \\
\hline Polygons (count) & & & \\
SFIR & 327 & 121 & 448 \\
Beaver Creek (BC) & 197 & 86 & 283 \\
Tipton Creek (TC) & 209 & 78 & 287 \\
Total area $\left(\mathrm{m}^{2}\right)$ & & & \\
SFIR & $-57,553$ & 15,429 & $-42,124$ \\
BC & $-41,384$ & 12,923 & $-28,461$ \\
TC & $-22,840$ & 8,249 & $-14,591$ \\
Volume $\left(\mathrm{m}^{3}\right)$ & & & \\
SFIR & $-61,246$ & 14,270 & $-46,976$ \\
BC & $-41,617$ & 9,517 & $-32,100$ \\
TC & $-15,060$ & 9,356 & $-5,704$ \\
Volume by bank $\left(\mathrm{m}^{3}\right)$ & & & \\
SFIR left & $-19,867$ & 7,327 & $-12,540$ \\
SFIR right & $-41,379$ & 6,943 & $-34,436$ \\
BC left & $-27,535$ & 4,351 & $-23,185$ \\
BC right & $-14,082$ & 5,166 & $-8,916$ \\
TC left & $-2,643$ & 8,404 & 5,761 \\
TC right & $-12,417$ & 952 & $-11,465$ \\
& & & \\
\hline
\end{tabular}

\section{Table 2}

Summary statistics for comparison among streams. 2002 measures differ from what Yan et al. (2010) reported because stream banks were newly digitized and the studies' extents slightly varied.

\begin{tabular}{llccc}
\hline Variable & Year & South Fork & Beaver Creek & Tipton Creek \\
\hline Channel length $(\mathrm{m})$ & 2002 & 51,494 & 25,409 & 30,150 \\
& 2009 & 51,364 & 24,878 & 29,432 \\
Sinuosity & 2002 & 2.30 & 1.50 & 1.95 \\
& 2009 & 2.30 & 1.47 & 1.89 \\
$\Delta$ Elevation $(\mathrm{m})$ & 2009 & 45.1 & 44.6 & 38.6 \\
Stream gradient $\left(\mathrm{m} \mathrm{m}^{-1}\right)$ & 2009 & 0.0020 & 0.0026 & 0.0025 \\
Widening ratio $(\mathrm{m})$ & 2009 & -0.82 & -1.14 & -0.49 \\
& & & &
\end{tabular}

favorable. Absolute differences were based on transect-averaged data. Most (12) of these 22 differences were less than $0.5 \mathrm{~m}(1.65 \mathrm{ft})$, and all but four showed transect averages differed by less than $1 \mathrm{~m}(3.3 \mathrm{ft})$. The four transects with larger absolute errors (figure 5a) were explained by use of differing elevation reference datum for transects coinciding with heavier forest cover. However, relative differences within transects, calculated by comparing deviations from transect mean and pooled among 316 survey points, showed a mean value of $0 \mathrm{~m}$, and standard deviation of $0.45 \mathrm{~m}$ (1.5 ft) (figure 5b). Relative elevation differences did not exceed $1.75 \mathrm{~m}(5.7$ $\mathrm{ft})$, and relative errors less than $0.25 \mathrm{~m}(0.82$ ft) (figure $5 b$ ), i.e., less than half the median bank heights for erosional polygons along all three reaches (table 3), were typical.

Land Cover and Stream Movement. Differences in bank movement among the streams (table 1) would have been related not only to the type of land cover, but the condition of vegetation comprising that cover. Zaimes et al. (2008) reported greater bank losses along continuous grazed pastures versus rotationally grazed or nongrazed (Conservation Reserve Program [CRP]) grasses. Unfortunately, satellite imagery used to classify and map land cover data (USDA NASS 2016) cannot be used to discern condition of grass stands. The "perennial grass" cover class we evaluated included both grazed and nongrazed cover of perennial grasses. Informal field observations made during low elevation helicopter flights along these streams in November of 2008 and April of 2009 (figure 6) suggested that more of the areas in the perennial grass cover class along Beaver Creek were continuously grazed than were the areas in the perennial grass cover class along the other two streams. In addition, we observed narrow strips of ungrazed grasses between the stream and adjacent cropland; often these grassy stream banks were too narrow to be detected by satellite imagery and were narrower than typically found among USDA CRP buffers (figure 6). A review by Schultz et al. (2009) found that a buffer width three times the bank height can control bank erosion. Therefore, buffers less than $6 \mathrm{~m}(33 \mathrm{ft})$ wide (i.e., less than half the $20 \mathrm{~m}[65.6 \mathrm{ft}]$ grid size for the land use data) can control bank erosion in settings where bank heights are less than 2 $\mathrm{m}(6.5 \mathrm{ft})$ high, which is a greater height than estimated for most eroded polygons along these streams (table 3 ).

We pursued the question of consistency of land cover data with locations of bank erosion polygons further using binomial statistics. The lengths of stream bank that were eroded beyond the $4 \mathrm{~m}(13.1 \mathrm{ft})$ digitizing tolerance comprised between 16\% and 21\% of the total bank lengths, with the greatest of these proportions occurring along Beaver Creek (table 4). Annual cropping did not dominate riparian land use, as $76 \%$ to $88 \%$ of the stream bank lengths were bordered by perennial vegetation, either perennial grass cover or forest, among these streams (table 4). The stream bank lengths bordered by annual row cropping comprised $6.5 \%$ of the bank length of the SFIR, 14.3\% of Tipton Creek, and $20 \%$ of the bank length along Beaver Creek. Noting that the proportion of eroded stream bank bordered by perennial grasses along Beaver Creek exceeded the proportion of total stream bank bordered by perennial grasses by $>8 \%(72.5 \%$ versus $64.3 \%$; table 4 ), and that Beaver Creek had the greatest proportion of stream bank that was eroded, we set up a binomial test to evaluate whether significantly more eroded banks were adjacent to perennial grasses along Beaver Creek than would be expected, if land cover had no effect on the location of erosional polygons. This was set up using polygon count data, as follows. If we believe that land cover bordering the stream does not affect the distribution of bank erosion polygons, then the 


\section{Figure 5}

Histograms of elevation differences between GPS and LiDAR derived elevations along 22 transects. Histogram (a) depicts differences in transect averages, while histogram (b) depicts differences by point/grid cell for all transects.

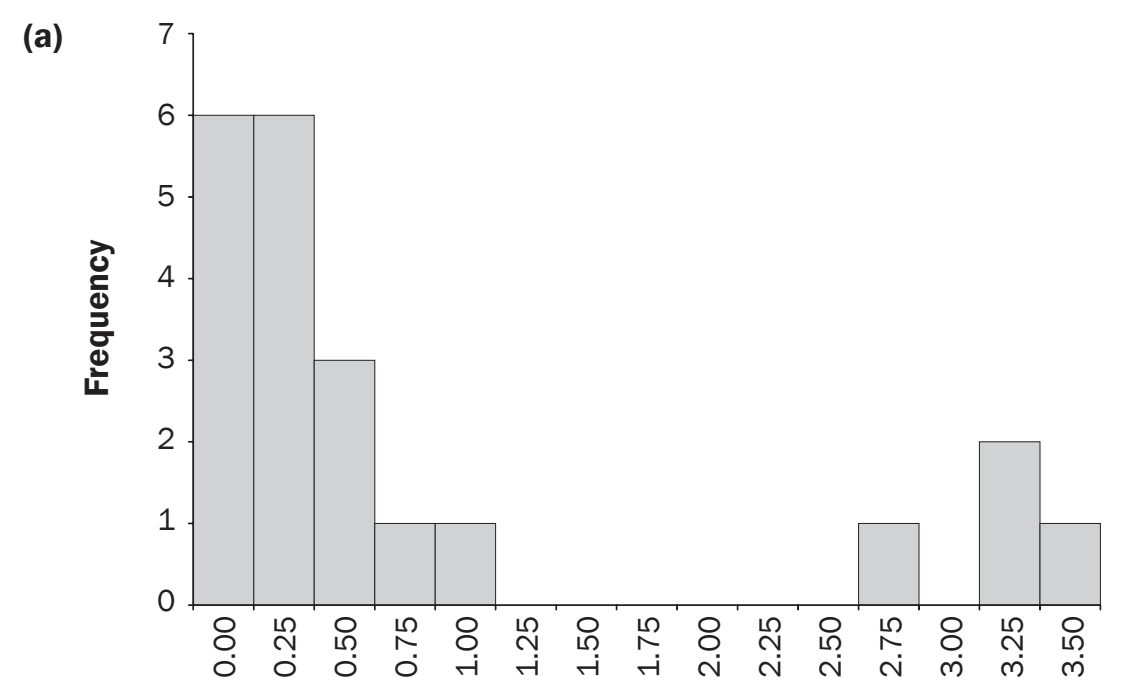

(b)

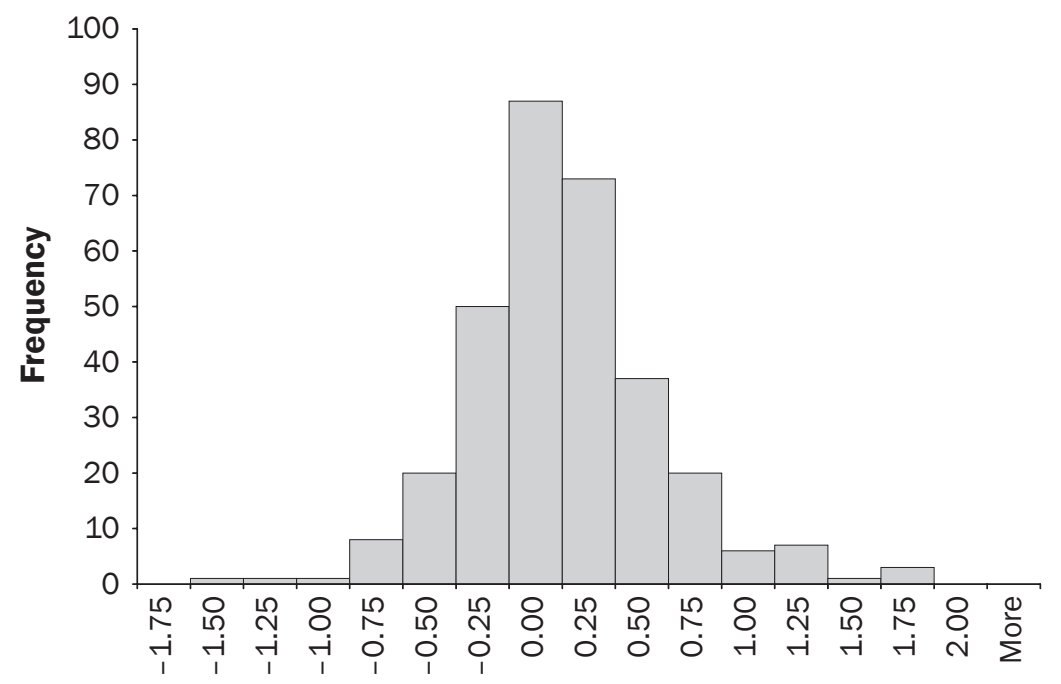

Table 3

Descriptive statistics of bank heights for erosional polygons along the three reaches.

\begin{tabular}{llll}
\hline Erosional bank heights $(\mathbf{m})$ & South Fork & Beaver Creek & Tipton Creek \\
\hline Median & 0.77 & 0.90 & 0.62 \\
95th percentile & 1.74 & 2.12 & 1.23 \\
Maximum & 7.59 & 3.69 & 3.01
\end{tabular}

fraction of total stream length occupied by each cover type would estimate the fraction of erosional polygons we would expect under each cover type. Along Beaver Creek, 64.3\% of the bank lengths were bordered by peren- nial grass. Given that 197 erosional polygons were observed along Beaver Creek, we would then expect to observe 127 of those polygons $[\mathrm{E}(x)=\mathrm{np}=197 \times 0.643=127]$ to border perennial grass cover. This estimate, given binomial statistical theory, would have a standard deviation $(\mathrm{SD})$ of $6.7[\mathrm{SD}(x)=$ $\left.\mathrm{np}(1-\mathrm{p})^{0.5}=(197 \times 0.643 \times 0.357)^{0.5}=6.7\right]$. Therefore, with $95 \%$ frequency, we would expect the observed number of erosional polygons bordered by perennial grass cover to be between 113 and 140 (i.e., $127 \pm 1.96$ $\times 6.7)$. Given that the observed value of 142 polygons was outside this 95\% confidence interval, we can conclude that the stream banks bordered by perennial grass cover were more erodible along Beaver Creek than the other two streams, where the observed and expected values were within one standard deviation of each other (data necessary to perform these calculations are given in table 4). Similarly, we found that the number of erosional polygons found along banks bordered by cropland were less than expected along Tipton and Beaver creeks. This was particularly true along Beaver Creek where we would have expected between 28 and 50 erosional polygons with 95\% frequency, but only counted 20 such polygons. The 19 erosional polygons adjoining cropland along Tipton Creek was only one less than we would have anticipated to be within a 95\% confidence interval. We conclude that narrow nongrazed buffers must have protected many of the stream banks adjoined by cropland along the two smaller streams. We examined all 20 erosional polygons adjacent to cropland along Beaver Creek using 2009 images and only found two instances of cultivation right to the stream edge (not shown). A literature review by Schultz et al. (2009) concluded that narrow grass buffers (6 to $10 \mathrm{~m}$ [20 to $30 \mathrm{ft}$ ] wide) protect stream banks from erosion. Intensively grazed pastures apparently dominated the perennial grass cover type to the greatest extent along Beaver Creek. Observations made during helicopter flights supported this interpretation (figure 6).

Mass Loss Estimates. Assuming a bulk

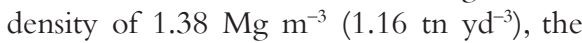
results indicated nearly $117,000 \mathrm{Mg}(129,000$ tn) of sediment loss associated with bank losses along these three streams. Remarkably, this total represents, on average, $1.1 \mathrm{Mg}(1.2$ tn) mass loss of bank material per meter of channel length. Again, the differences among the three streams were substantial, with perunit-of-stream-length mass losses of $1.77 \mathrm{Mg}$ $\mathrm{m}^{-1}\left(1.78 \mathrm{tn} \mathrm{yd}^{-1}\right)$ for Beaver Creek, $1.26 \mathrm{Mg}$ $\mathrm{m}^{-1}\left(1.27 \mathrm{tn} \mathrm{yd}^{-1}\right)$ for the SFIR, and $0.27 \mathrm{Mg}$ $\mathrm{m}^{-1}\left(0.27 \mathrm{tn} \mathrm{yd}^{-1}\right)$ for Tipton Creek. The total 


\section{Figure 6}

Evidence that bank erosion differs between ( $a$ and $b$ ) areas of continuously grazed perennial grass cover and ( $c$ and d) areas in perennial grass that are not continuously grazed. Labels indicate where (South Fork lowa River [SFIR], Beaver Creek, or Tipton Creek) each photograph was taken. (c and d) show examples where cropped areas adjacent to the stream had narrow riparian buffer zones that helped stabilize banks; these buffers may or may not have been in the USDA Conservation Reserve Program. Photos were taken during helicopter flights during November of 2008 and April of 2009.

(a)

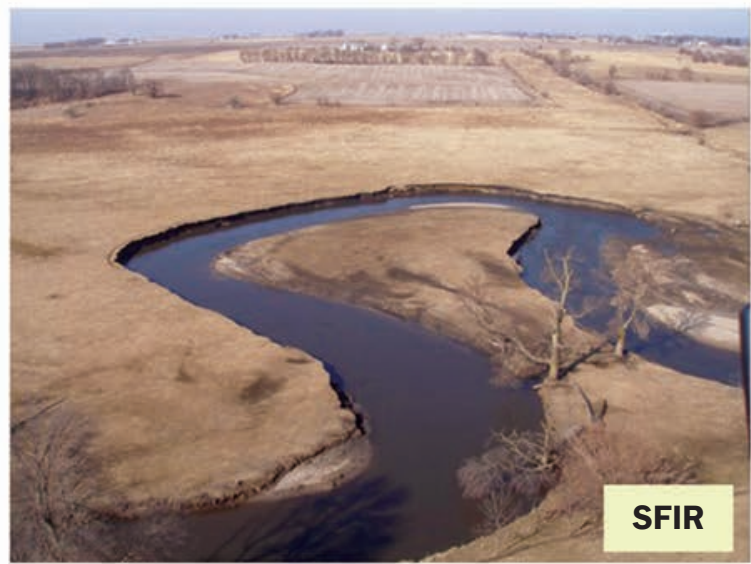

(c)

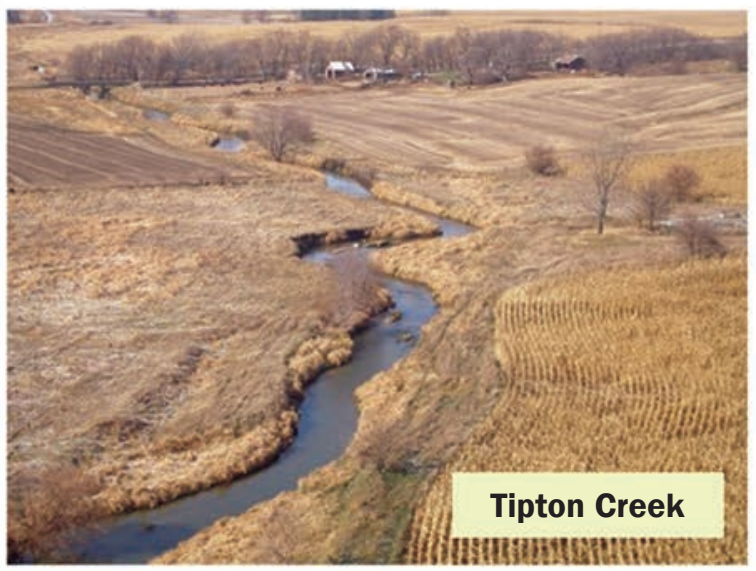

(b)

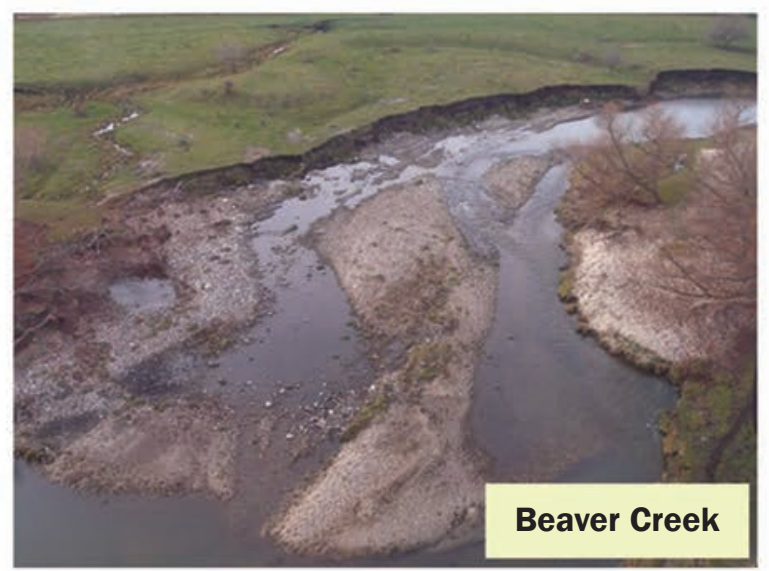

(d)

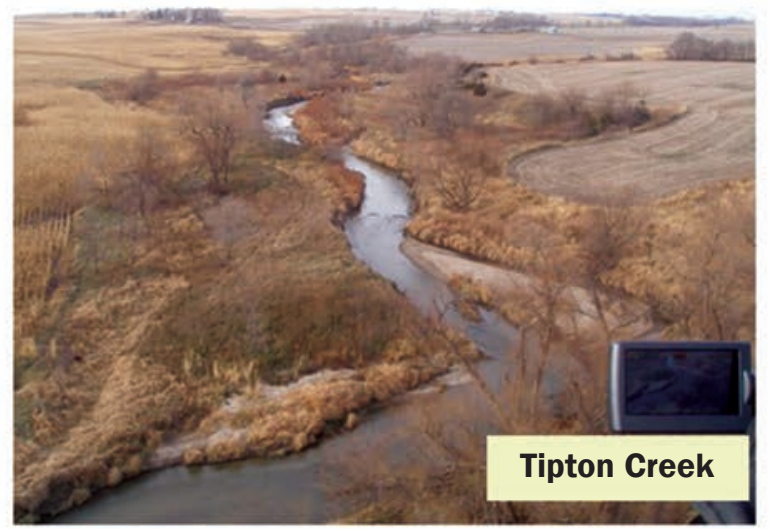

mass loss estimated for Tipton Creek and the SFIR was estimated at about $72,700 \mathrm{Mg}$ $(80,138$ tn). These two streams are located above a gage site along the middle section of the SFIR. Hubbard et al. (2011) estimated that daily sediment load during the June of 2008 floods peaked at more than 10,000 $\mathrm{Mg} \mathrm{d}^{-1}\left(11,023\right.$ tn day $\left.^{-1}\right)$. Unfortunately, the 2008 floods closed nearly every bridge in this watershed, and access to obtain sediment concentration data necessary to obtain total loads was not possible. However, clearly the bank losses we estimated would account for a large portion of the stream sediment load during 2008 flooding. There were also substantial upland soil losses that occurred, as well as over bank sediment deposition onto the floodplain, observed by Yan et al. (2010) to be as much as $0.1 \mathrm{~m}$ (4 in) thick while investigating accumulation of postsettlement alluvium in these valleys.
Bank Movement along the Middle South Fork Iowa River. The middle section of the SFIR, between the confluences of Tipton and Beaver creeks, showed substantially greater amounts of bank movement than the tributary streams. The length of this reach was 9.85 $\mathrm{km}(6.1 \mathrm{mi})$, and the total drainage area just above the confluence with Beaver Creek was about 59,650 ha $(147,350 \mathrm{ac})$. The sinuosity was 1.66 , indicating the channel had been straightened, but not as much as Beaver Creek. This overlay of 2002 and 2009 bank lines showed 103 erosional polygons, the largest being $4,312 \mathrm{~m}^{2}(1.06 \mathrm{ac})$ in area and the total area was 4.69 ha $(11.6 \mathrm{ac})$. In contrast, only 14 depositional polygons were found, which totaled 0.29 ha $(0.72 \mathrm{ac})$ in size. The net loss of bank material along this length of channel was estimated at 58,191 $\mathrm{m}^{3}\left(2,054,995.8 \mathrm{ft}^{3}\right)$, with a mass of $80,304 \mathrm{Mg}(88,334 \mathrm{tn})$. This volume loss was $5.9 \mathrm{~m}^{3} \mathrm{~m}^{-1}\left(63.5 \mathrm{ft}^{3} \mathrm{ft}^{-1}\right)$ of channel length. This was more than $5 \mathrm{~m}^{3} \mathrm{~m}^{-1}$ $\left(53.8 \mathrm{ft}^{3} \mathrm{ft}^{-1}\right)$ of channel, which was calculated for the Blue Earth River in Minnesota during 2001 to 2002 using data reported by Thoma et al. (2005). Banks higher than $3 \mathrm{~m}$ (10 ft) high are common along the Blue Earth River, but not along the SFIR. This middle reach of the SFIR was widened by an estimated 4.47 $\mathrm{m}(14.7 \mathrm{ft})$ by the $2008 \mathrm{flood}$, and the mass loss per unit of stream length was $8.15 \mathrm{Mg}$ $\mathrm{m}^{-1}$ (9.8 $\mathrm{tn} \mathrm{yd}^{-1}$ of channel length). The large increase in loss per-unit-length indicates that downstream of the SFIR-Tipton confluence, the 2008 flood substantially changed this reach of the SFIR channel.

\section{Summary and Conclusions}

The estimated bank losses reported here reflect the impact of an extreme event on channel widening and sediment losses. Including both reaches of the SFIR, more 
Table 4

Lengths of stream bank that showed movement (erosion and deposition) along three stream reaches and percentage adjoining land cover, compared to total lengths and lengths showing no movement (stable).

\begin{tabular}{|c|c|c|c|c|c|}
\hline \multirow[b]{2}{*}{ Stream/movement } & \multirow[b]{2}{*}{ Bank length $(m)$} & \multicolumn{4}{|c|}{ Land use cover $(\%)^{*}$} \\
\hline & & Perennial grass & Crop & Forest & Other \\
\hline \multicolumn{6}{|l|}{ Tipton Creek } \\
\hline Deposition & 3,008 & 48 & 7 & 36 & 9 \\
\hline Stable & 46,669 & 48 & 15 & 30 & 7 \\
\hline Total & 59,077 & 49 & 14 & 30 & 7 \\
\hline \multicolumn{6}{|l|}{ Beaver Creek } \\
\hline Erosion & 10,457 & 72 & 12 & 14 & 2 \\
\hline Deposition & 3,240 & 69 & 11 & 18 & 2 \\
\hline Stable & 36,244 & 62 & 23 & 11 & 4 \\
\hline Total & 49,941 & 64 & 20 & 12 & 4 \\
\hline Stable & 78,118 & 50 & 9 & 35 & 6 \\
\hline Total & 103,072 & 50 & 7 & 38 & 5 \\
\hline Erosional polygons (count) & - & 167 & 17 & 129 & 14 \\
\hline
\end{tabular}

Note: $1,610 \mathrm{~m}=1 \mathrm{mi}$.

*Erosional polygons measured as (count), not measured as a percentage.

than $12 \mathrm{ha}(30 \mathrm{ac})$ were added to the watershed channels during the 2008 flood and events that led up to it. Against the impact and magnitude of the 2008 flood event, there is the indication that where riparian areas are protected by perennial ungrazed grasses, substantial damage and bank movement during even the largest events can be reduced, at least along our smaller streams. Current climate trends may be increasing the frequency of large precipitation events, and there is concern that conservation practices will need to be adapted and increased in extent/cover to meet this challenge (Garbrecht et al. 2014). Our results indicate riparian management practices can have a key role in adapting to ongoing climate change and mitigating the impacts of large events on stream channels.

\section{References}

Garbrecht, J.D., M.A. Nearing, F.D. Shields, M.D. Tomer, E.J. Sadler,J.V.Bonta, and C. Baffaut. 2014. Impact of weather and climate scenarios on conservation assessment outcomes. Journal of Soil and Water Conservation 69(5):374-392, doi:10.2489/jswc.69.5.374.

Gray, S.M., F.M.E. Bieber, L.H. McDonnell, L.J. Chapman, and N.E. Mandrak. 2014. Experimental evidence for species-specific response to turbidity in imperiled fishes. Aquatic Conservation: Marine and Freshwater Ecosystems 24:546-560
Hubbard, L.E., D.W. Kolpin, S.J. Kalkhoff, and D.M Robertson. 2011. Nutrient and sediment concentrations and corresponding loads during the historic June 2008 flooding in eastern Iowa. Journal of Environmental Quality 40:166-175.

Iowa State University. 2009. Iowa Geographic Map Server http://ortho.gis.iastate.edu/.

Kalkhoff, S.J., L.E. Hubbard, M.D. Tomer, and D.E. James. 2016. Effect of variable annual precipitation and nutrient input on nitrogen and phosphorus transport from two Midwestern agricultural watersheds. Science of the Total Environment 559:53-62

Kessler, A.C., S.C. Gupta, H.A.S. Dolliver, and D.P. Thoma 2012. Lidar quantification of bank erosion in Blue Earth County, Minnesota. Journal of Environmental Quality 41:197-207.

Knox, J.C. 2006. Floodplain sedimentation in the Upper Mississippi Valley: Natural versus human accelerated. Geomorphology 79:286-310.

Lecce, S.A. 1997. Spatial patterns of historical overbank sedimentation and floodplain evolution, Blue River, Wisconsin. Geomorphology 18:265-277.

Micheli, E.R., and J.W. Kirchner. 2002. Effects of wet meadow riparian vegetation on streambank erosion.

2. Measurements of vegetated bank strength and consequences for failure mechanics. Earth Surface Processes and Landforms 27:687-697.

Montgomery, D.R. 2007. Dirt: The Erosion of Civilization Berkeley, CA: University of California Press.
Palmer, J.A., K.E. Schilling, T.M. Isenhart, R.C. Schultz, and M.D. Tomer. 2014. Streambank erosion rates and loads within a single watershed: Bridging the gap between temporal and spatial scales. Geomorphology 209:66-78.

Prior, J.C. 1991. Landforms of Iowa. Iowa City, IA: University of Iowa Press.

Quist, M.C., and R.D. Schultz. 2014. Effects of management legacies on stream fish and aquatic benthic macroinvertebrate assemblages. Environmental Management 54:449-464.

Rhoads, B.L., and S.T. Kenworthy. 1998. Time-averaged flow structure in the central region of a stream confluence. Earth Surface Processes and Landforms 23:171-191.

Schultz, R.C., T.M. Isenhart, J.P. Colletti,W.W. Simpkins, R.P. Udawatta, and P.L. Schultz. 2009. Riparian and upland buffer practices. In North American Agroforestry: An Integrated Science and Practice, ed. H.E. Garret, 163218. Madison, WI: American Society of Agronomy.

Simon, A., and L. Klimetz. 2008. Relative magnitudes and sources of sediment in benchmark watersheds of the Conservation Effects Assessment Project. Journal of Soil and Water Conservation 63(6):504-522, doi:10.2489/ jswc.63.6.504.

Simon, A., and M. Rinaldi. 2006. Disturbance, stream incision, and channel evolution: The roles of excess transport capacity and boundary materials in controlling channel response. Geomorphology 79:361-383.

Thoma, D.P., S.C. Gupta, M.E. Bauer, and C.E. Kirchoff. 2005. Airborne laser scanning for riverbank erosion 
assessment. Remote Sensing of the Environment 95:493-501.

Tomer, M.D., T.B. Moorman, D.E. James, G. Hadish, and C.G. Rossi. 2008a. Assessment of the Iowa River's South Fork Watershed: Part 2. Conservation Practices. Journal of Soil and Water Conservation 63(6):370-379, doi:10.2489/jswc.63.6.371.

Tomer, M.D., T.B. Moorman, J.L. Kovar, K.J. Cole, and D.J. Nichols. 2016. Eleven years of runoff and phosphorus losses from two fields with and without manure application, Iowa, USA. Agricultural Water Management 168:104-111.

Tomer, M.D., T.B. Moorman, and C.G. Rossi. 2008b. Assessment of the Iowa River's South Fork Watershed: Part 1. Water Quality. Journal of Soil and Water Conservation 63(6):360-370, doi:10.2489/ jswc.63.6.360.

Tomer, M.D., S.A. Porter, K.M.B. Boomer, D.E. James, J.A. Kostel, M.J. Helmers, T.M. Isenhart, and E. McLellan. 2015. Agricultural Conservation Planning Framework: 1. Developing multi-practice watershed planning scenarios and assessing nutrient reduction potential. Journal of Environmental Quality 44(3):754-767.

Tomer, M.D., C.G.Wilson, T.B. Moorman, K.J. Cole, D. Heer, and T.M. Isenhart. 2010. Source-pathway separation of multiple contaminants during a rainfall-runoff event in an artificially drained agricultural watershed. Journal of Environmental Quality 39(3):882-895.

Trimble, S.W. 1999. Decreased rates of alluvial sediment storage in the Coon Creek Basin, Wisconsin, 1975-93. Science 285:1244-1246.

Tufekcioglu, M., T.M. Isenhart, R.C. Schultz, D.A. Bear, J.L. Kovar, and J.R. Russell. 2012. Stream bank erosion as a source of sediment and phosphorus in grazed pastured of the Rathbun Lake watershed in southern Iowa, United States. Journal of Soil and Water Conservation 67(6):545-555, doi:10.2489/jswc.67.6.545.

USDA NASS (National Agricultural Statistics Service). 2016. Cropscape and Cropland Data Layer. Washington, DC: USDA National Agricultural Statistics Service. https:// www.nass.usda.gov/Research_and_Science/Cropland/ SARS1a.php.

Walter, R.C., and D.J. Merritts. 2008. Natural streams and the legacy of water-powered mills. Science 319:299-304.

Wesche, T.A., and D.J. Isaak. 1999. Watershed management and land use practices. In Inland Fisheries Management in North America, 2nd edition, ed. C.C. Kohler and W.A. Hubert, 217-245. Bethesda, MD: American Fisheries Society.

Wilson, C.G., R.A. Kuhnle, D.D. Bosch, J.L. Steiner, P.J. Starks, M.D. Tomer, and G.V.Wilson. 2008. Quantifying relative contributions from sediment sources in Conservation Effects Assessment Project watersheds. Journal of Soil and Water Conservation 63(6):523-532, doi:10.2489/jswc.63.6.523.

Yan, B., M.D. Tomer, and D.E. James. 2010. Historical channel movement and sediment accretion along the
South Fork of the Iowa River. Journal of Soil and Water Conservation 65(1):1-8, doi:10.2489/jswc.65.1.1.

Zaimes, G., R. Schultz, and T. Isenhart. 2008. Streambank soil and phosphorus losses under different riparian land uses. Journal of American Water Resources Association 44:935-947. 